\title{
A new cercaria and metacercaria of Acanthoparyphium (Echinostomatidae) found in an intertidal snail Zeacumantus subcarinatus (Batillaridae) from New Zealand
}

\author{
Sergio R. Martorelli ${ }^{\mathrm{a}, *}{ }$, Robert Poulin ${ }^{\mathrm{b}}$, Kim N. Mouritsen ${ }^{\mathrm{c}}$ \\ ${ }^{a}$ Centro de Estudios Parasitólogicos y Vectores (CEPAVE) 2 Nro. 584, 1900 La Plata, Buenos Aires, Argentina \\ ${ }^{\mathrm{b}}$ Department of Zoology, University of Otago, PO Box 56, Dunedin, New Zealand \\ c Department of Marine Ecology, University of Aarhus, Finlandsgade 14, DK-8200, Aarhus N, Denmark
}

Received 27 September 2005; received in revised form 4 January 2006; accepted 11 February 2006

Available online 6 March 2006

\begin{abstract}
A new 23-collar-spined cercaria and metacercaria are described from intertidal molluscs of the coast of New Zealand. The new cercaria found emerging from the mud snails Zeacumantus subcarinatus (Sowerby) (Prosobranchia: Batillariidae) is characterized mainly by the number and arrangement of the cephalic glands, the size of the suckers, and the size and number of the collar spines. The cercaria encysts in the cockle Austrovenus stutchburyi (Wood) (Bivalvia: Veneridae) which lives in sympatry with the first intermediate host throughout New Zealand. Laboratory infections of cockles by cercariae from naturally infected snails resulted in metacercariae identical to those found in naturally infected cockles. The main features of the cercaria and metacercaria are the presence of a reniform collar with 23 spines, two pairs of small cephalic glands at the oral sucker level, another two pairs of much longer ones posterior to the pharynx, and the excretory vesicle Y-shaped with the main collecting canals extending to the anterior level of the ventral sucker. Each of the main collecting canals had 10-11 pairs of bilateral diverticula between the anterior edge of the ventral sucker and anterior body end. A brief discussion of its possible life cycle and ecology is also provided. (C) 2006 Elsevier Ireland Ltd. All rights reserved.
\end{abstract}

Keywords: Acanthoparyphium; A new cercaria; Metacercaria; Mollusk; New Zealand

\section{Introduction}

The presence of cercariae of the family Echinostomatidae Looss, 1899, has been widely reported from different marine areas around the world. During a parasitological survey of molluscs from intertidal areas of South Island, New Zealand, 23-spined cercariae and metacercariae were recovered, respectively, from the endemic mud snail Zeacumantus subcarinatus (Sowerby) (Prosobranchia: Batillariidae) and the cockle Austrovenus stutchburyi (Wood) (Bivalvia: Veneridae). The morphological features of these larvae clearly place them in the genus Acanthoparyphium Dietz, 1909. This genus has been documented as parasitizing snails and birds in marine areas of

\footnotetext{
* Corresponding author. Tel.: +54 0221 4233471; fax: +54 02214232327.

E-mail address: sergio@cepave.edu.ar (S.R. Martorelli).
}

USA, Philippines, Korea, Kuwait, India, Puerto Rico, Japan and Australia. Acanthoparyphium tyosenense Yamaguti, 1939 has also been reported in humans in Korea [1-3]. In New Zealand two species have been reported from bird hosts: Acanthoparyphium spinulosum Johnston, 1917 from Limosa lapponica baueri [4] and Acanthoparyphium sp. from Haematopus ostralegus finschi [5].

Life cycles of species of Acanthoparyphium have been published for A. spinulosum [6,7], Acanthoparyphium paracharadrii Velazquez, 1964 [8], and A. tyosenense [9].

In this paper, a new cercaria and metacercaria of this genus are described and illustrated. A brief discussion of their possible life cycle and cercarial behavior information is also provided.

\section{Materials and methods}

Infected mud snails (Z. subcarinatus) were collected by hand in Lower Portobello Bay, Otago Harbour, South Island, New 
Zealand $\left(45^{\circ} 47^{\prime} \mathrm{S}, 170^{\circ} 42^{\prime} \mathrm{E}\right)$, and kept alive in the laboratory individually in $5-\mathrm{ml}$ Petri dishes at $25^{\circ} \mathrm{C}$ and under constant illumination to promote cercarial emission.

Cercariae were studied alive, and some specimens were fixed with nearly boiling saline and, after $2 \mathrm{~min}$, they were transferred to AFA solution (containing 85\% ethanol, formalin and glacial acetic acid), in which they were kept for approximately $24 \mathrm{~h}$. The specimens were then preserved in 5\% formalin. Infected snails were crushed and rediae were fixed in 5\% formalin. The rediae and cercariae described herein were taken from four mud snails. One additional individual of $Z$. subcarinatus was kept alive in the laboratory during 7 months for the study of live cercariae and their patterns of emergence.

Cockles (A. stutchburyi) were collected in the same place (Otago Harbour in Lower Portobello Bay) as the mud snail, and dissected for metacercariae. Metacercariae with 23 collar spines were found encysted in the foot of the cockles. Encysted metacercariae of Curtuteria australis Allison, 1979 (Echinostomatidae) with 31 collar spines also were obtained.

Encysted metacercariae $(n=44)$ collected from three cockles were placed in small Petri dishes containing saline solution at $40-42{ }^{\circ} \mathrm{C}$ to facilitate excystment. Excysted metacercariae were fixed in hot saline solution, transferred to AFA, and then preserved in 5\% formalin until their subsequent study.

Fixed rediae, cercariae and metacercariae were stained with Semichon's acetocarmine or Harris haematoxylin, dehydrated in an ethanol series, cleared in clove oil and mounted in Canada balsam.

Live specimens of cercariae were also stained with neutral red for cephalic gland observation.

Measurements of the rediae, cercariae, and metacercariae were based on whole-mounted specimens and given in micrometers as the range. The voucher specimens of cercariae and excysted metacercariae were deposited in the Museo de La Plata, La Plata, Argentina, Helminthological Collection (MPHC) under the numbers: 5537-5538.

\section{Results}

Larval stages of Acanthoparyphium sp.

\subsection{Redia}

Redia probably in daughter stage with collar, and elongate body, 740-870 long and 160-180 wide. Pharynx 50-55 long and 48-55 wide, followed by a short intestine 200-230 long. One pair of posterior ambulatory buds was present at $430-620$ from anterior end. Birth pore was evident at $120-140$ from mouth. More developed or mature rediae were yellowish, including well-developed cercariae, immature forms and numerous germ bodies (Fig. 3).

\subsection{Cercaria}

Description was based on 10 live cercariae. Measurements were based on 10 fixed specimens. Echinostome cercariae with simple tail were $230-325$ long by $20-30$ wide. Body spinous was $400-520$ long by $105-180$ wide, with abundant cystogenous glands filled with rod-like bodies in region from pharynx to posterior body end. Collar reniform; collar spines 23 in total number, similar in shape and size (7-8 long by $3-4$ wide at basal level), were arranged in a dorsally uninterrupted single row. Oral sucker (OS) was circular, 35-50 in diameter, with mouth subterminal; prepharynx short, 23-45 long; pharynx muscular, 20-26 long by 18-24 wide; esophagus $86-150$ long; intestinal caeca reaching posterior end of the body. Ventral sucker (VS) at mid-ventral level of the body was 52-72 in diameter. Sucker ratio (OS/VS) was 0.69 . Two pairs of small cephalic glands at oral sucker level were almost median, each with a duct opening at anterior end of body. Another two pairs of much larger ones were submedian, posterior to pharynx, each with a duct opening at anterior end of body. Each duct has a

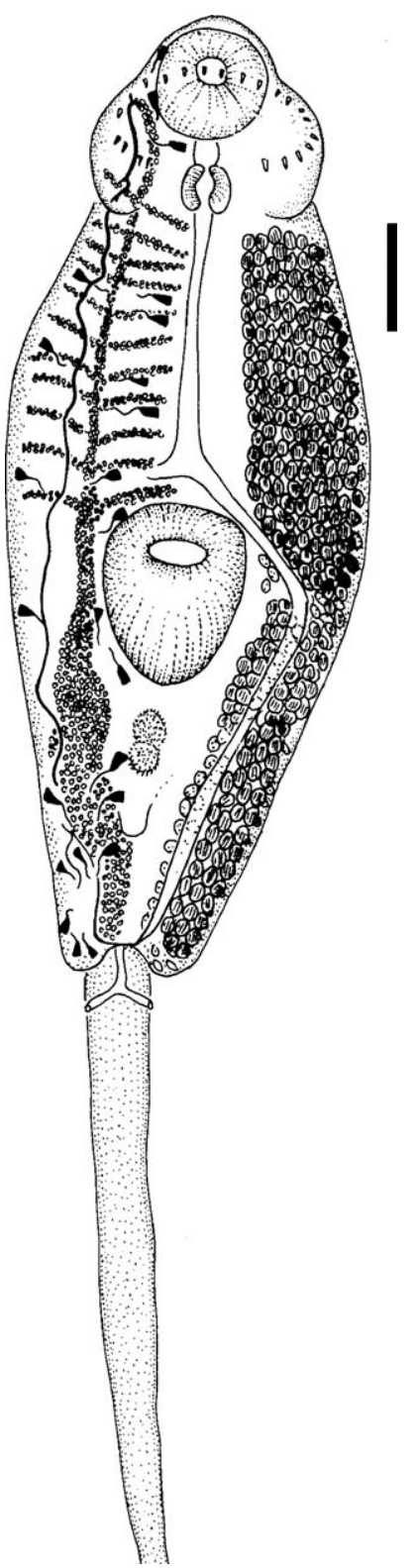

Fig. 1. Cercaria from Zeacumantus subcarinatus, ventral view. Scale bar $=45 \mu \mathrm{m}$. 
prominent reservoir at oral sucker level. All these glands were stained well with neutral red. Two genital primordia were present, tandem, posterior to ventral sucker (Figs. 1-2, 6).

Excretory vesicle was Y-shaped, with main collecting canals extending to anterior level of ventral sucker. Main collecting canals have 10-11 pairs of bilateral diverticula between anterior edge of ventral sucker and anterior end of body. Excretory vesicle, main collecting canals and diverticula were filled with spherical concretions. Flame cells were 24 in total on each side of body; flame cell formula $2[(3+3+3+3)+(3+3+3+3)]=48$. Tail excretory canal extends short in tall, bifurcating, opening at 2 lateral pores near base.

These cercariae emerged from the snail around the midday, lived for 24-36 h, and showed a positive phototaxis. Cercariae also swam on along the bottom, showing a negative geotaxis. In two instances, some specimens encysted on the bottom of the dish, forming a delicate, 200-250 $\mu \mathrm{m}$ diameter cyst (Figs. 4-5, 7).

\subsection{Metacercaria}

Based on 10 whole-mounted specimens. Metacercarial cyst was spherical, $380-470$ in diameter, with a bilayered wall. In live and fixed metacercariae it was possible to see the collar spines, the suckers and the excretory organs filled with concretions through the cyst wall (Figs. 5-7).

Excysted metacercariae with well-developed reniform collar with 23 spines. Body elongate, spinous, widest at ventral sucker level, 350-450 long by 100-142 wide. Spines were 18-26 long by $7-10$ wide at basal level. Oral sucker was subterminal, $36-$ 45 in diameter. Ventral sucker was $50-67$ long by $50-67$ wide. Sucker ratio (OS/VS) was 0.66. Prepharynx was 27-42 long; pharynx 28-31 long by 19-22 wide; esophagus 90-118 long; intestinal caeca reaching posterior end of body. Testes tandem

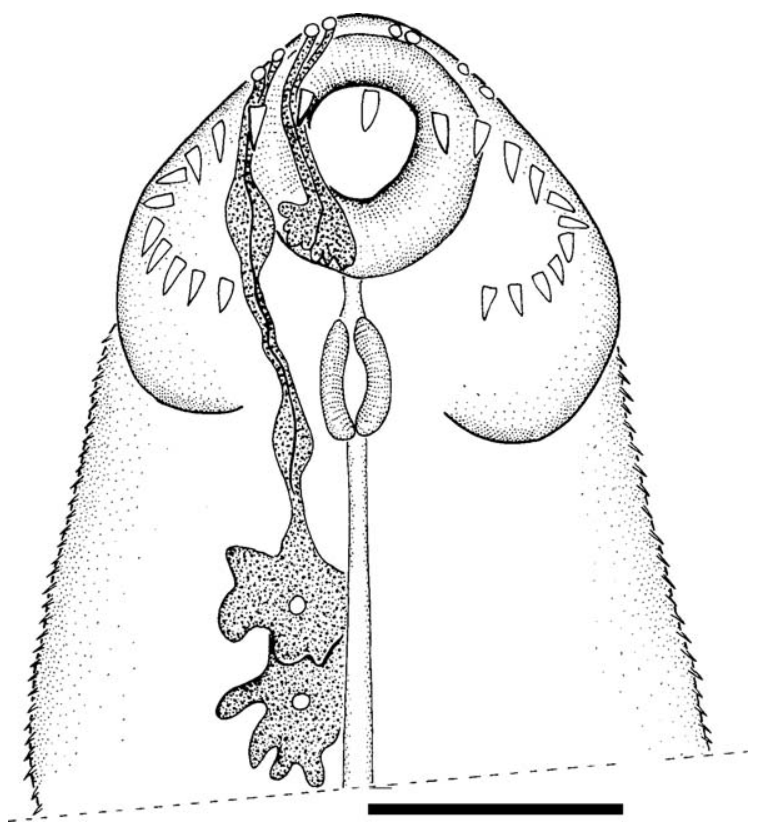

Fig. 2. Cercaria from Zeacumantus subcarinatus showing cephalic glands, ventral view. Scale bar $=50 \mu \mathrm{m}$.

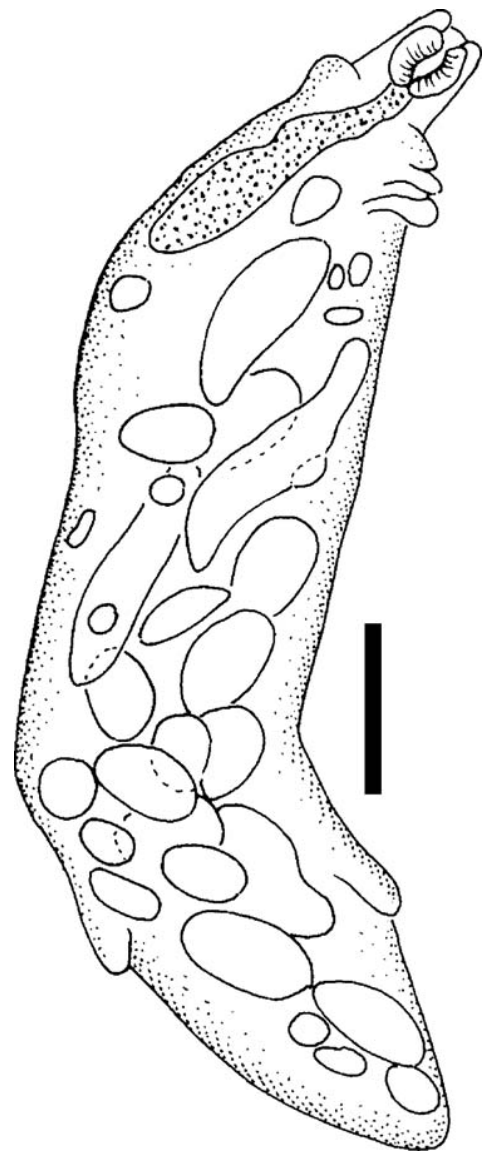

Fig. 3. Redia from Zeacumantus subcarinatus. Scale Bar $=100 \mu \mathrm{m}$.

was median. Ovary median was posterior to ventral sucker. Terminal genitalia were dorsal to ventral sucker. Genital pore was anterior to ventral sucker. Excretory vesicle was Y-shaped as in cercaria; main collecting canals extending to anterior level of ventral sucker, each with $10-11$ pairs of bilateral diverticula.

Comments: The metacercarial stage was found in the foot of the cockle $A$. stutchburyi, in the same area where the infected snails were collected, and preliminary laboratory infections of cockles with cercariae resulted in metacercariae identical to

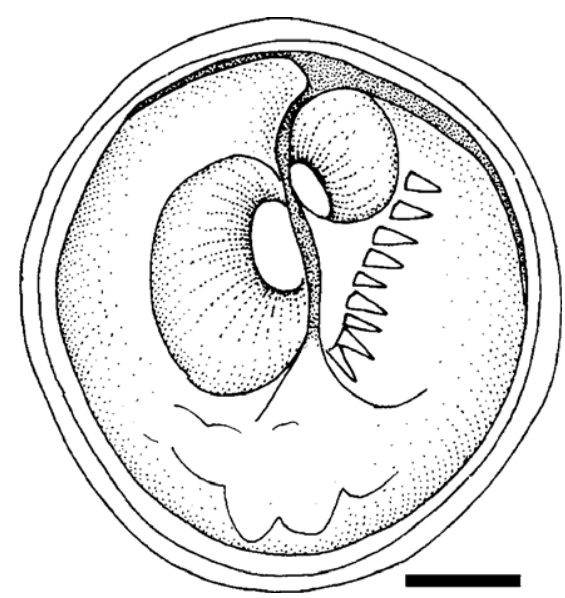

Fig. 4. Encysted from Astrovenus stutchburyi. Scale bar $=100 \mu \mathrm{m}$. 


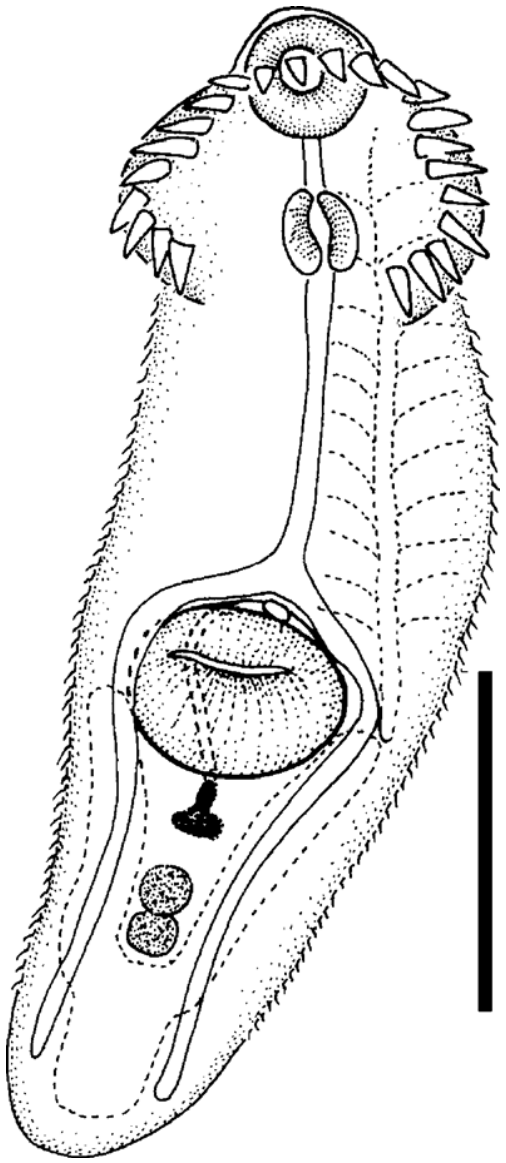

Fig. 5. Excysted metacercaria from Austrovenus stutchburyi, ventral view. Scale bar $=100 \mu \mathrm{m}$.

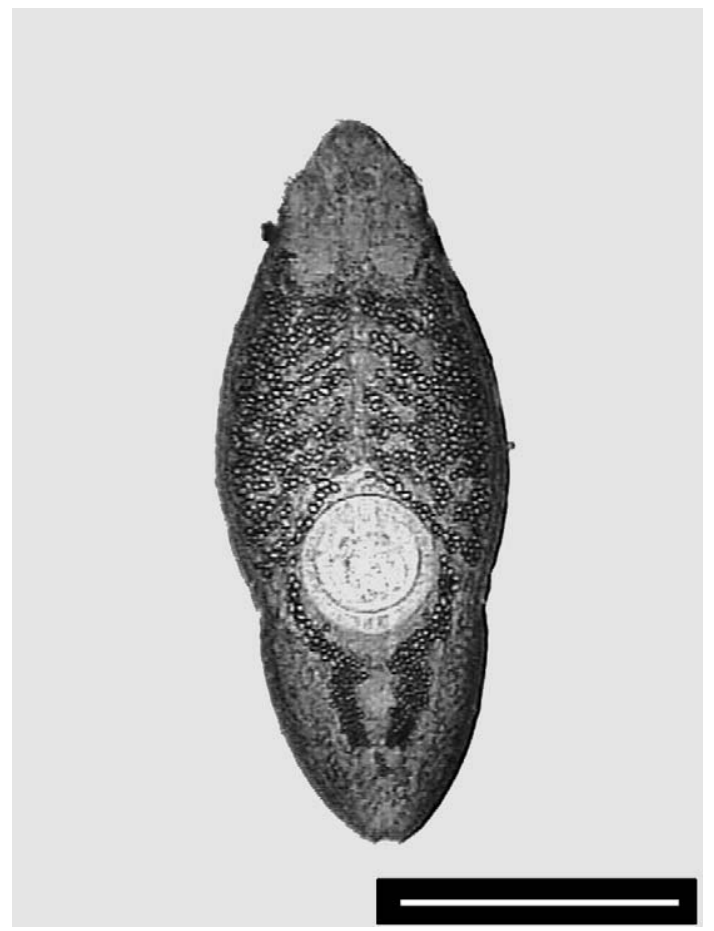

Fig. 6. Cercaria from Zeacumantus subcarinatus, showing concretions in excretory organs stained with neutral red. Scale bar $=150 \mu \mathrm{m}$.

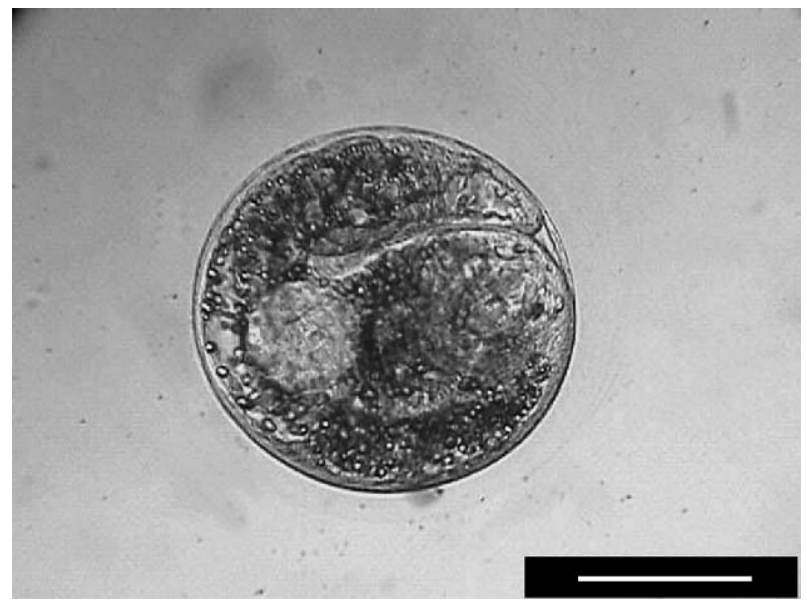

Fig. 7. Encysted metacercaria on Petridishes. Scale bar $=200 \mu \mathrm{m}$

those found in naturally infected cockles. Based on the lack of other suitable bivalve hosts for the cercariae in the study area, and on the morphological similarities between the cercariae and metacercariae, they are assumed to represent different stages of the same species. This has now been confirmed by a comparison of micro satellite DNA from both the cercariae and metacercariae in naturally infected hosts, indicating that they belong to the same species (Leung T, Keeney D, Poulin R, unpublished data).

This new species appears to have the same life cycle as $C$. australis, already described from New Zealand (Allison 1979) [4]. The oystercatchers $H$. ostralegus Linnaeus, and H. unicolor Forster are likely to be the definitive hosts because no other bird feeds on cockles in the Otago Harbour area except occasionally gulls, Larus spp.

\section{Discussion}

The present cercaria had a reniform collar. The collar spines were 23 in total number, all similar in shape and size, and arranged in a dorsally uninterrupted single row. The main excretory canals had bilateral diverticula. Consequently, it can be placed in Acanthoparyphium Dietz, 1909. According to Fried [10], the best known species in this genus is A. spinulosum Johnston, 1917, with its life cycle first described in Australia [6]. Several cercariae belonging to this genus have been reported from marine snails worldwide: Cercaria of Acanthoparyphium sp. [11], cercaria of $A$. paracharadrii [8], cercaria of A. spinulosum [6], Cercaria caribea II [12], Cercaria bengalensis II [13], C. queenslandae I [14], C. yamagutii [15] (=cercaria of A. tyosenense [9]), Cercaria kuwaitae XI [16], and Cercaria sp. XVI [17]. All these cercariae are very similar in relation to their body size, general body shape, and general aspect of the main collecting canals with diverticula. The number of flame cells differs among related cercariae, but this number has not always been given by the previous authors. The present cercaria is similar in relation to its flame cell formula to the cercaria of A. spinulosum [6] and Cercaria yamagutii [15]. With respect to the number and position of the cephalic glands, some differences could be established between all previously described cercariae and the present one (Table 1). In addition, 
Table 1

Number of pairs of the cephalic glands in cercariae of Acanthoparyphium

\begin{tabular}{lll}
\hline Cercaria & Oral sucker level & Pharyngeal level \\
\hline Cercaria sp. XVI [17] & 6 & 2 \\
Cercaria queenslandae [14] & 1 & 2 \\
Cercaria of A. spinulosum [6] & 0 & 6 \\
C. yamagutii [15] & 0 & 3 \\
Cercaria of A. paracharadrii [8] & 0 & 0 \\
Cercaria caribea II [12] & 1 & 3 \\
Cercaria kuwaitae XI [16] & 1 & 2 \\
Cercaria bengalensis II [13] & 1 & 6 \\
Cercaria of Acanthoparyphium sp. & 2 & 2 \\
$\quad$ present work) & & \\
\hline
\end{tabular}

the number of the glands in the oral and pharyngeal positions can be used to differentiate some cercariae from the others. In this context the present cercaria is different from all previous ones in having the four pairs of the cephalic glands, two pairs of which at the oral sucker level and the other two at the post pharyngeal level.

Adults belonging to Acanthoparyphium which were reported from New Zealand as Acanthoparyphium sp. in the godwit $L$. lapponica baueri Nauman [4] and the oystercatcher $H$. ostralegus finschi Martens [5]. Most likely these represent the adult stage of the present new cercariae.

Comparisons can be made between the new cercaria and the cercariae described from Australia, Cercaria queenslandae I [14] and Cercaria of A. spinulosum [6]. The new cercaria can be differentiated from Cercaria queeslandae I mainly by number of the collar spines, 23 instead of 25 [14]. The latter also has smaller suckers and only one pair of the cephalic glands at the oral sucker level, unlike two in the new. In relation to the cercaria of A. spinulosum [6] the new cercaria can be distinguished by its bigger oral and ventral suckers (35-50 and 52-72 instead 21 and 49 in A spinulosum), and its different number of the cephalic glands $(2+2$ instead $0+6$ in the cercaria from Australia). In summary, the principal differences between the new cercaria and all previously described cercariae of Acanthoparyphium are in the number and disposition of the cephalic glands, the size of suckers, and the size and number of collar spines.

Finally this newly described Acanthoparyphium metacercaria appears to be roughly as abundant as another echinostome, $C$. australis (see [18]). Practically $100 \%$ of cockles harbour a mixture of metacercariae from the two species, with numbers of metacercariae per cockle ranging from just a few to well over one thousand. Thus metacercariae of both $C$. australis and the new Acanthoparyphium species impair the ability of cockles to burrow under the sediment, and then cause the increase of the predation by the oystercatcher on cockles $([19,20]$. Both parasites also might contribute to the changes in the benthic community that result from the accumulation of cockles on the sediment surface after they lose their ability to burrow [21].

\section{Acknowledgements}

The authors are grateful to Felicia Cardillo for his excellent technical assistance in the laboratory. This work was funded in part by a research grant from the Marsden Fund (New Zealand) to R. Poulin, and by a research grant from CONICET to $S$ Martorelli.

\section{References}

[1] Seo BS, Hong ST, Chai JY, Lee SH. Studies on intestinal trematodes in Korea: VIII. A human case of Echinostoma hortense infection. Korean J Parasitol 1983;21:219-23.

[2] Chai JY, Lee SH. Food-borne intestinal trematode infections in the Republic of Korea. Parasitol Int 2002;51:129-54.

[3] Chai JY, Han ET, Park YK, Guk SM, Lee SH. Acanthoparyphium tyosenense: the discovery of human infection and identification of its source. J Parasitol 2001;87:794-800.

[4] Allison FR. Records of trematodes and cestodes of the bar-tailed godwit, Limosa lapponica baueri Nauman from New Zealand. Rec Canterbury Mus 2001;15:9-10.

[5] McKenna PB. Checklist of helminth and protozoan parasites of birds in New Zealand. Surveillance (Wellington) 1998;25:3-12 [special Issue].

[6] Bearup AJ. Life history of Acanthoparyphium spinulosum Johnston, 1917 (Trematoda: Echinostomatidae). Aust J Zool 1960;8:217-25.

[7] Martin WE, Adams JE. Life cycle of Acanthoparyphium spinulosum Johnston, 1917 (Echinostomatidae: Trematoda). J Parasitol 1961;47: 777-82.

[8] Velazquez CC. Life history of Acanthoparyphium paracharadrii sp. $\mathrm{n}$. (Trematoda: Echinostomatidae). J Parasitol 1964;50:261-5.

[9] Kim YG, Yu JE, Chung EY, Chung PR. Acanthoparyphium tyosenense (Digenea: Echinostomatidae): experimental confirmation of the cercaria and its complete life history in Korea. J Parasitol 2004;90:97-102.

[10] Fried B. Biology of echinostomes except Echinostoma. Adv Parasitol 2001;49:163-210.

[11] Yamaguti S. Studies on the helminth fauna of Japan: Part. 3. Avian trematodes: II. Jpn J Zool 1934;5:543-83.

[12] Cable RM. Scientific survey of Porto Rico and the Virgin Islands. Marine cercariae of Puerto Rico. NY Acad Sci 1956;16:491-577.

[13] Mani GK, Rao H. Studies on Indian marine cercariae: two new echinostome cercariae. Proc Helminthol Soc Wash 1993;60:250-5.

[14] Cannon LRG. Marine cercariae from the gastropod Cerithium moniliferum Kiener at Heron Island, Great Barrier Reef. Proc R Soc Queens 1978;89:45-57.

[15] Ito J. Studies on the brackish water cercariae in Japan. III. Three new echinostome cercariae in Tokyo Bay, with a list of Japanese echinostome cercariae (Trematoda). Jpn J Med Sci Biol 1957;10:439-53.

[16] Abdul-Salam J, Sreelatha B. Studies on cercariae from Kuwait Bay: XI. Description and surface topography of Cercaria kuwaitae XI sp.n. (Digenea: Echinostomatidae). Mem Ins Oswaldo Cruz 1999;94:743-50.

[17] Wardle WJ. A survey of the occurrence, distribution and incidence of infection of helminth parasites of marine and estuarine mollusks from Galveston, Texas. Dissertation for Doctor of Philosophy degree. Texas A and M University; 1974. p319.

[18] Babirat C, Mouritsen KN, Poulin R. Equal partnership: two trematode species, not one, manipulate the burrowing behaviour of the New Zealand cockle, Austrovenus stutchburyi. J Helminthol 2004;78:95-199.

[19] Thomas F, Poulin R. Manipulation of a mollusk by a trophically transmitted parasite: convergent evolution or phylogenetic inheritance? Parasitology 1998;116:431-6.

[20] Mouritsen KN. The parasite-induced surfacing behaviour in the cockle Austrovenus stutchburyi: a test of an alternative hypothesis and identification of potential mechanisms. Parasitology 2002;124:521-8.

[21] Mouritsen KN, Poulin R. Parasites boost biodiversity and change animal community structure by trait-mediated indirect effects. Oikos 2005;108: $344-50$. 